\title{
PACIENTŲ, SERGANČIU ŠLAPIMO PŪSLĖS VĖŽIU, ŠLAPIMO PŪSLĖS TŪRIO POKYČIO IR DUBENS POZICIONAVIMO TIKSLUMO İVERTINIMAS RADIOTERAPIJOJE
}

\author{
Aurimas Krauleidis, Aista Plieskienė, Vanda Andrijaitiené \\ Klaipédos universitetiné ligoniné
}

Raktažodžiai: šlapimo pūslès vėžys, vaizdais valdoma radioterapija, paciento pozicionavimo paklaida.

\begin{abstract}
Santrauka
Kasdieniai šlapimo pūslès tūrio ir dubens padèties pozicionavimo pokyčiai gali turèti ịtakos taikinio (naviko) apšvitinimo tikslumui ir homogeniškumui. Ši radioterapijos problema ypač aktuali klinikinejje praktikoje, esant ribotiems ištekliams. Darbo tikslas - kiekybiškai ịvertinti šlapimo pūslès tūrio ir padèties pokyčius invazinio šlapimo pūslès véžio gydymo radioterapija metu ir nustatyti radioterapijos skyriuje (RS) gydytų pacientų dubens pozicionavimo paklaidą. Šlapimo pūslès pradinio klinikinio švitinimo taikinio tūrio (CTV) ir planuojamo apšvitinti taikinio tūrio (PTV) pokyčiams įvertinti pacientai kiekvieną savaitę buvo skenuojami kompiuteriniu tomografu SOMATOM sensation open (su virtualios simuliacijos funkcija), adaptuojant bei koreguojant švitinimo tūrius ir vertinant jų pokyčius radioterapijos metu. Atliekant kasdienị skaitmeninès rekonstrukcijos radiologinị paciento padèties patikrinimą, įvertintas dubens pozicionavimo tikslumas $\mathrm{x}, \mathrm{y}, \mathrm{z}$ ašyse. Pateikta retrospektyvi duomenu analizè. Tyrimo rezultatai parodè, kad radioterapijos gydymo metu pacientų vidutinis šlapimo pūslès tūris svyravo neženkliai (didžiausi nuokrypiai nuo 15,75 iki 20,75 procento). Reikšmingų tūrio pokyčių nenustatyta. Buvo pastebèti ir įvertinti šlapimo pūslès padèties pokyčiai, kai šlapimo pūslès tūris nepateko ị pradinį CTV, tačiau jų tūrio reikšmès dydis nebuvo didelis, visais atvejais atitinkantis PTV, tad buvo homogeniškai apšvitintas. Nenustatyta su pacientais susijusių veiksnių, kurie galètų kliniškai skatinti šlapimo pūslès tūrio pokyčius. Retrospektyviai vertinant dubens kaulinių anatominių struktūrų judejimo poslinkio statistinès imties nuokrypius visomis trimis ašių kryptimis: vertikaliaja, išilgine ir šonine, nustatyta RS pacientų dubens pozicionavimo paklaida, kuri dažniausiai buvo ne didesnè nei $5 \mathrm{~mm}$. Prieita prie iš-
\end{abstract}

vados, kad tinkamas paciento imobilizavimas, kruopštus pozicionavimas, šlapimo pūslès ištuštinimo instrukcijų išaiškinimas ir jų laikymosi kontroliavimas sumažina galimus netikslumus, švitinant sergančiuosius invaziniu šlapimo pūslès vėžiu. Neturint galimybès prieš kiekvieną procedūrą ịvertinti organo tūrio pokyčių ribų, tikslus paciento pozicionavimo protokolo vykdymas RS, kasdienès radiologinès verifikacijos ir kontrolinis radioterapijos perplanavimas, adaptuojantis prie anatominių struktūrų, šlapimo pūslès ir naviko tūrio pokyčių, užtikrina saugų radikalios dozès realizavimą.

\section{Ivadas}

Mokslo tyrimais įrodyta, kad pagrindinis invazinio šlapimo pūslès véžio gydymas yra radikali cistektomija [1], tačiau šiuolaikinès radioterapijos pasiekimai ir galimybès atskleide, kad radikalaus chemospindulinio gydymo rezultatai prilygsta chirurginiams ir išsaugo organo funkciją [1-3]. Vis dèlto, švitinant šios srities navikus, radioterapijos komanda susiduria su iššūkiais, kurie siejami su švitinamo organo bei kritinių organų tūrio pokyčiais [3-5]. Vaizdais valdomos šlapimo pūslès véžio radioterapijos esmè - kruopštus paciento pozicionavimas ir judančio organo padèties nustatymas. Dél šių priežasčiu gali būti pasirenkamos didesnès PTV ribos, tačiau didesnès ribos didina dozę kritiniams organams ir riboja radikalios radioterapijos suminès dozès realizavimą $i$ naviką. Didesnè dozė kritiniams organams gali sukelti šalutinį radioterapijos poveikị: tuštinimosi sutrikimus, šlapimo nelaikymą, viduriavimą ir didesnes komplikacijas, tokias kaip žarnyno stenozè, fistulès ir kontraktūros $[3,6,7]$.

Esant ribotiems ištekliams, $\mathrm{RS}$ neturint $3 \mathrm{D}$ vaizdinimo radioterapijos radiologinei verifikacijai, labai svarbu kiekybiškai ịvertinti paciento, gydomo dèl invazinio šlapimo pūslès vèžio, pozicionavimo tikslumą bei šlapimo pūslès tūrio ir padeties pokyčius radioterapijos metu.

Tyrimo tikslas - kiekybiškai ịvertinti šlapimo pūslès tūrio ir padèties pokyčius invazinio šlapimo pūslès vėžio 
gydymo radioterapija metu ir nustatyti radioterapijos skyriuje (RS) gydytų pacientų dubens pozicionavimo paklaidą.

\section{Tyrimo medžiaga ir metodai}

Retrospektyviam tyrimui buvo atsitiktinai atrinkti trys pacientai, kuriems $2020 \mathrm{~m}$. taikyta išorinè radioterapija dèl invazinio šlapimo pūslès vėžio. Visi pacientams taikyta vienoda paruošimo radioterapijai metodika, naudojamos tos pačios imobilizacinès priemonès bei rekomenduota pagal paciento paruošimo protokolą ištuštinti šlapimo pūslę. Radioterapijos planavimui naudotas kompiuterinis tomografas Siemens SOMATOM sensation open su virtualios simuliacijos funkcija LAP Laser. Kompiuterinès tomografijos vaizdinimui tiriamieji buvo skenuojami $3 \mathrm{~mm}$ storio pjūviais.

Kompiuterinès tomografjos vaizdai buvo nusiųsti ị radioterapijos gydymo planavimo sistemą „Eclipse ${ }^{\mathrm{TM}} 15.6^{\prime}$ (Varian Medical Systems). Gydymo planai buvo skaičiuojami planavimo sistema „Eclipse TM 15.6“ (Varian Medical Systems), naudojant AAA (Analytical anisotropic algorithm) skaičiavimo algoritmą. Radioterapijos procedūros realizuotos linijiniu greitintuvu UNIQUE MV 6, naudojant arkinio (rotacinio) moduliuojamo intensyvumo radioterapijos VMAT (Volumetric Modulated ARC Therapy) metodiką ir 2D MV portalini vaizdinimą. Paciento padèties verifikacijos atliktos prieš kiekvieną radioterapijos procedūrą, naudojant 2D MV.

Klinikinejje RS praktikoje dar nèra galimybès atlikti radioterapijos trimačio vaizdo kontrolès, kuri ypač svarbi švitinant šlapimo pūslę vèžio atveju, nes tai tuščiaviduris organas. Tyrimo laikotarpiu radiologinei radioterapijos kontrolei, iš anksto neįspeję paciento, radioterapijai dedikuotu kompiuteriniu tomografu atlikome kassavaitini kartotini paciento skenavimą su dozimetriniu perplanavimu. Kiekvienos procedūros metu paciento padèties patikrinimui naudojome 2D MV portalinị vaizdinimą. Radioterapijos eigoje, atliekant kontrolinius kompiuterinès tomografijos skenavimus, buvo vertinamas CTV ir jo ribos, atsižvelgiant ị PTV pokytị ir gydymo plano izodozinị pasiskirstymą po radioterapijos

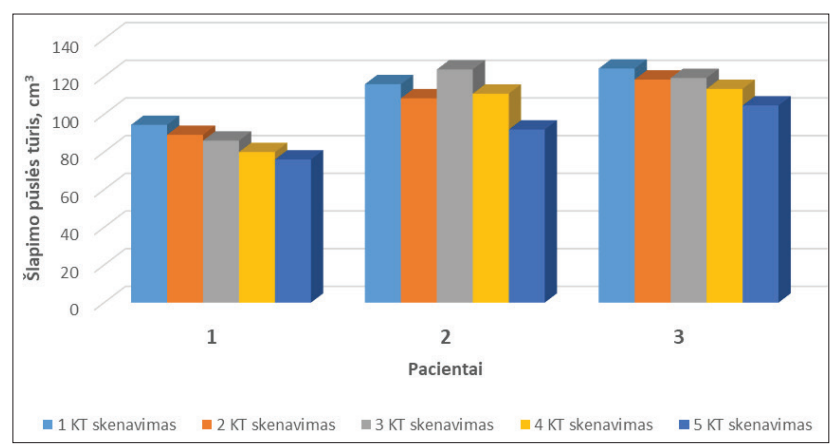

1 pav. Šlapimo pūslès tūrio pokyčiai radikalios radioterapijos metu perplanavimo. Nustatytas kritinių organų ir švitinamo tūrio dozès pasiskirstymo pokytis.

Siekiant sudaryti vienodas sąlygas pagal paciento paruošimo protokolą, pacientui buvo nurodyta visiškai ištuštinti šlapimo pūslę prieš radioterapijos perplanavimą kompiuteriniu tomografu ir iškart prieš kasdienę radioterapijos procedūrą. Pagal standartinị radioterapijos protokolą, klinikiniai švitinimo tūriai kontūruojami kompiuterinès tomografijos vaizduose po kiekvieno skenavimo. PTV buvo sukurtas pridedant anizotropines ribas (po 1,0 cm ị kairę, ị dešinę, i apatinę ir užpakalinę puses ir po $1,5 \mathrm{~cm}$ ị priekinę ir viršutinę puses). Palyginimui vertintas šlapimo pūslès tūrio pokytis, atskaitos tašku pasirenkant šlapimo pūslès tūrị, išmatuotą pirmosios kompiuterinès tomografijos vaizduose, atliktos radioterapijos planavimui.

Siekiant retrospektyviai ịvertinti dubens anatominès srities pacientų pozicionavimo paklaidą RS, antrame tyrimo etape atsitiktinai atrinkti švitintų pacientų dubens anatominès srities 994 kasdieninių 2D MV (portalinio vaizdinimo) verifikacijų paklaidų radioterapijos metu duomenys ir atlikta jų analizè.

\section{Tyrimo rezultatai ir jų analizė}

Atsitiktinès atrankos būdu pilotiniam tyrimui retrospektyviai buvo atrinkti trys pacientai, sergantys invaziniu šlapimo pūslès vėžiu, kuriems skirta radikali radioterapija, realizuojant suminę dozę - 64,8 Gy, 36 fr. į naviką ir 45 Gy, 25 fr. i sritinius $1 / \mathrm{m}$. Šlapimo pūslès tūris svyravo nuo $71,52 \mathrm{~cm}^{3}$ iki $123,82 \mathrm{~cm}^{3}$. Gydymo metu kas savaitę pacientus kartotinai skenuojant kompiuteriniu tomografu, pastebeta tendencija, kad radioterapijos eigoje šlapimo pūslès tūris mažèjo ir padidejimas nustatytas tik vieno kartotinio skenavimo metu. Radioterapijos kurso metu kiekvienam pacientui atlikta po 5 kompiuterines tomografijas. Šlapimo pūslès tūrio pokyčiai pateikiami 1 paveiksle.

Radioterapijos metu paciento vidutinis šlapimo pūslès tūris svyravo neženkliai (didžiausi nuokrypiai nuo 15,75 iki 20,75 proc.). Reikšmingų tūrio pokyčių nenustatyta. Buvo pastebėti ir ịvertinti šlapimo pūslès padèties pokyčiai, kai

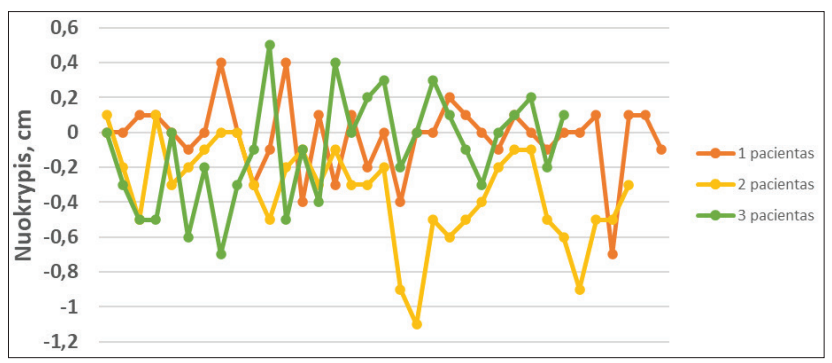

2 pav. Pacientų pozicionavimo paklaida (nuokrypis) išilginèje ašyje 
klinikinis šlapimo pūslès tūris nepateko ị CTV ribas, tačiau jų tūrio reikšmès dydis nebuvo didelis, visais atvejais atitiko PTV, tad buvo homogeniškai apšvitintas. Nenustatyta su pacientais susijusių veiksnių, galëjusių kliniškai paveikti šlapimo pūslès tūrio pokyčius. Retrospektyviai išanalizavus trijų pacientų, sergančių invaziniu šlapimo pūslès vėžiu, 2D MV (portalinio vaizdinimo) duomenis, paaiškejjo, kad kasdienių procedūrų metu pacientu pozicionavimo paklaida arba nuokrypiai, atliekant radiologinę dubens kaulinių struktūrų verifikaciją, dažniausiai neviršijo $5 \mathrm{~mm}$ ir tik vieną kartą siekẻ $11 \mathrm{~mm}$ išilginejje ašyje (2-4 pav.).

Išanalizavus pacientu pozicionavimo paklaidas išilgine, vertikalia ir šonine kryptimis nustateme, kad vertikalia kryptimi $90 \%$ visų kasdienių verifikaciju kaulinių anatominių struktūrų atžvilgiu pozicionavimo paklaidos buvo iki $\pm 3 \mathrm{~mm}$, išilgine kryptimi šios paklaidos sudare $-73 \%$, šonine kryptimi - 84 procentus (5-7 pav.).

Siekiant ịvertinti PTV ir kritinių organų gautas dozes, buvo analizuojamos dozès tūrio histogramos. Remiantis moksliniais straipsniais ir rekomendacijomis [6,8], paskirtosios dozès PTV tolerancijos ribos: minimali dozė $\mathrm{V}_{95}>95 \%$, maksimali $\mathrm{D}_{\max }<107$ procentai. Vertinant kritinių organų dozes, šlaunikaulio galvutès toleruojama dozė yra $\mathrm{D}_{100}<52 \mathrm{~Gy}$, tiesiosios žarnos $\mathrm{V}_{60}<35 \%, \mathrm{~V}_{65}<25 \%, \mathrm{~V}_{70}<20 \%$. Išanalizavę dozès tūrio histogramas, nustateme, kad visų pacientų planuose PTV $\mathrm{V}_{95}>98 \%$, dozés maksimumas svyravo nuo $103,5 \%$ iki 106,7 procento. Vertinant kritinių organų gautas dozes, nustatyta, kad paciento Nr. 1 dešinès šlaunikaulio galvutès $D_{100}$ 35,5 Gy, kairès - 32,5 Gy. Tiesiosios žarnos 35\% - 51,9 Gy, 25\% - 53,8 Gy, 20\% - 54,8 Gy. Paciento Nr. 2 dešinès šlaunikaulio galvutès $\mathrm{D}_{100}-24,8 \mathrm{~Gy}$, kairès - 24,5 Gy. Tiesiosios žarnos 35\% - 42,4 Gy, $25 \%$ - 46,8 Gy, 20\% - 49,4 Gy. Paciento Nr. 3 dešinès šlaunikaulio galvutės $D_{100}-29,1$ Gy, kairès - 26,2 Gy. Tiesiosios žarnos 35\% - 50,7 Gy, 25\% - 53,6 Gy, 20\% - 55 Gy.

Radikalus radioterapinis invazinio šlapimo pūslès vèžio gydymas taikomas pakankamai retai, todèl paciento pozicionavimo paklaidai RS įvertinti retrospektyviai naudoti $2017-2018 \mathrm{~m} .994$ pacienty švitintos anatominès dubens srities kasdienès radiologinès anatominių kaulinių struktūrų verifikacijos rezultatai. Pateikiami statistinès imties duomenys visomis ašių kryptimis: vertikaliaja, išilgine, šonine (1 lentelè).
İvertinus gautus rezultatus, vertikalioje ašyje $36 \%$ nuokrypio nenustatyta. Dažniausiai gautas mažiausias $\pm 1-3 \mathrm{~mm}$ nuokrypis (472 verifikacijose), nustatytas $47 \%$ visų (994) atvejų. Retai pasikartojo $\geq 6 \mathrm{~mm}$ poslinkis (59 verifikacijose), kuris sudaro $6 \%$ visu (994) atvejų.

Išilgineje ašyje nustatyti panašūs rezultatai. Didžiojoje radiologinių verifikacijų dalyje nuokrypio nebuvo (25\%), arba registruotas \pm 1 -3 mm poslinkis (492 verifikacijose), kuris sudaro $52 \%$ visu (994) atvejų. Mažiausiai užregistruotas $\geq 6$ mm nuokrypis ( 86 verifikacijose), kuris sudaro $9 \%$ visų (994) atvejų.

Šoninèje ašyje dubens pozicionavimo paklaidos taip pat dažniausiai nebuvo (27\%) arba ji siekè $\pm 1-3 \mathrm{~mm}$. Šis poslinkis nustatytas

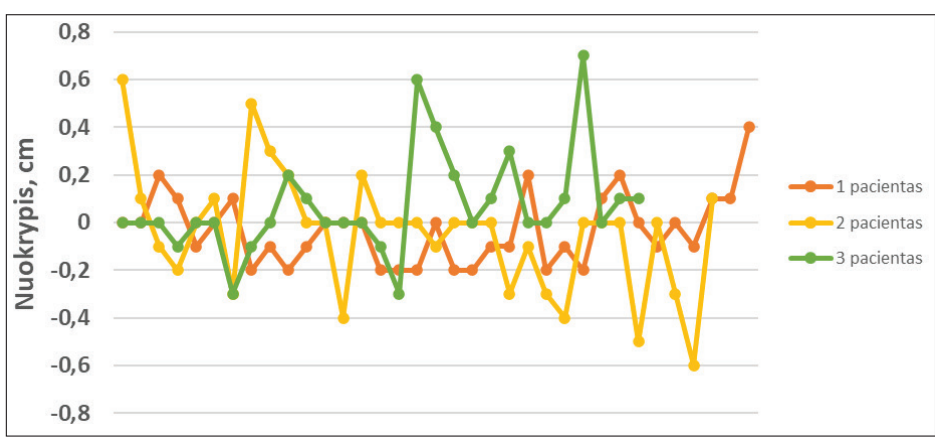

3 pav. Pacientų pozicionavimo paklaida (nuokrypis) vertikalioje ašyje

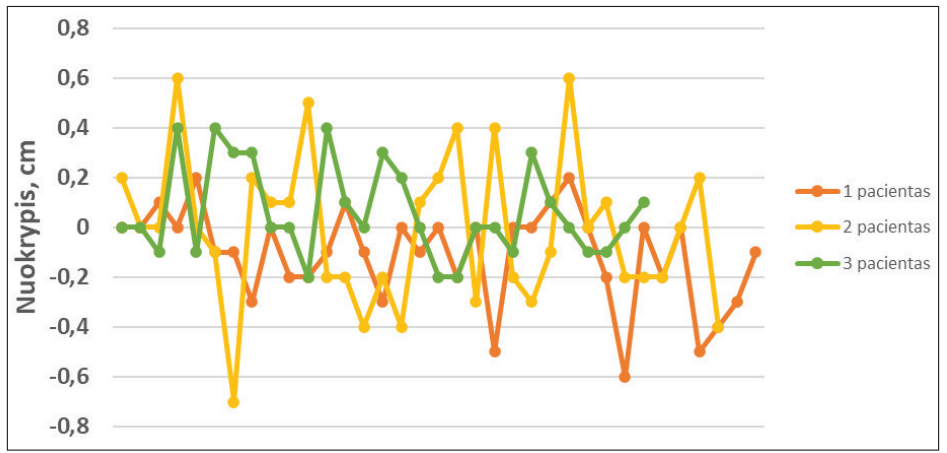

4 pav. Pacientų pozicionavimo paklaida (nuokrypis) šoninèje ašyje

1 lentelè. Nuokrypių vertinimas radiologinèse verifikacijose ( $\mathrm{n}=994)$.

Anatominè švitinimo sritis - dubuo, kontroliuojant pagal anatomines - kaulines struktüras. SD - standartinis nuokrypis.

\begin{tabular}{|l|l|l|l|}
\hline Nuokrypis & $\begin{array}{l}\text { Vertikalioje } \\
\text { ašyje }\end{array}$ & $\begin{array}{l}\text { Š o n i n è je e } \\
\text { ašyje }\end{array}$ & $\begin{array}{l}\text { Išilginėje } \\
\text { ašyje }\end{array}$ \\
\hline Nuokrypio nenustatyta $(0)$ & $351(36 \%)$ & $268(27 \%)$ & $246(25 \%)$ \\
\hline Nuokrypis $\pm 1-3 \mathrm{~mm}$ & $472(47 \%)$ & $506(51 \%)$ & $492(49 \%)$ \\
\hline Nuokrypis $\pm 4-5 \mathrm{~mm}$ & $112(11 \%)$ & $134(13 \%)$. & $148(15 \%)$ \\
\hline Nuokrypis $\pm 6 \mathrm{~mm}$ ir daugiau & $59(6 \%)$ & $108(11 \%)$ & $86(9 \%)$ \\
\hline Vidutinė verte் $\pm \mathrm{SD}, \mathrm{mm}$ & $1,7 \pm 1,8$ & $2,4 \pm 2,5$ & $2,2 \pm 2,3$ \\
\hline Maksimalus nuokrypis, $\mathrm{mm}$ & $+15 /-10$ & $+/-22$ & $+16 /-12$ \\
\hline Minimalus nuokrypis, $\mathrm{mm}$ & $+1 /-1$ & $+1 /-1$ & $+1 /-1$ \\
\hline
\end{tabular}


dažniausiai (506 verifikacijose) ir sudaro $51 \%$ visų (994) atvejų. Retai pasikartojo $\geq 6 \mathrm{~mm}$ nuokrypis (108 verifikacijose), kuris sudaro $11 \%$ visų (994) atvejų.

Literatūros šaltiniuose aprašyta šlapimo pūslès tūrio per sep-

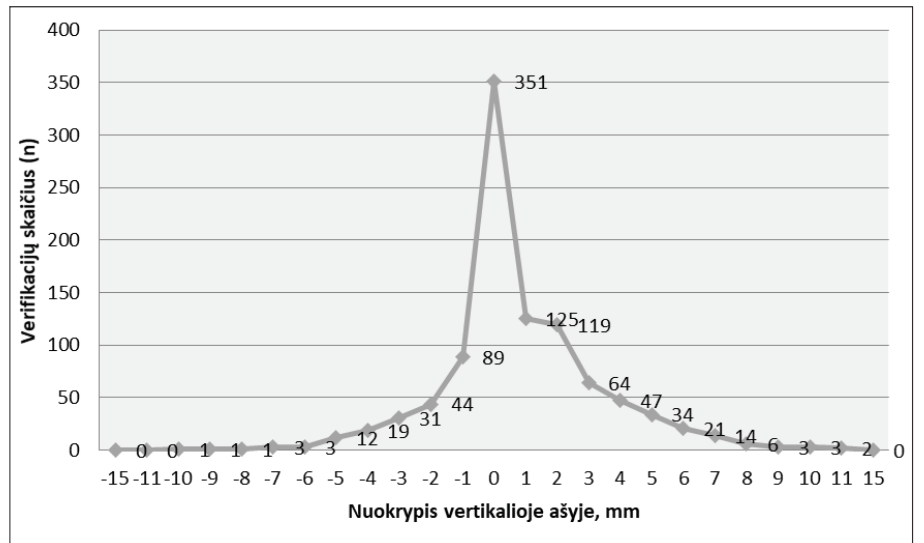

5 pav. Dubens anatominės srities pozicionavimo nuokrypis vertikalioje ašyje

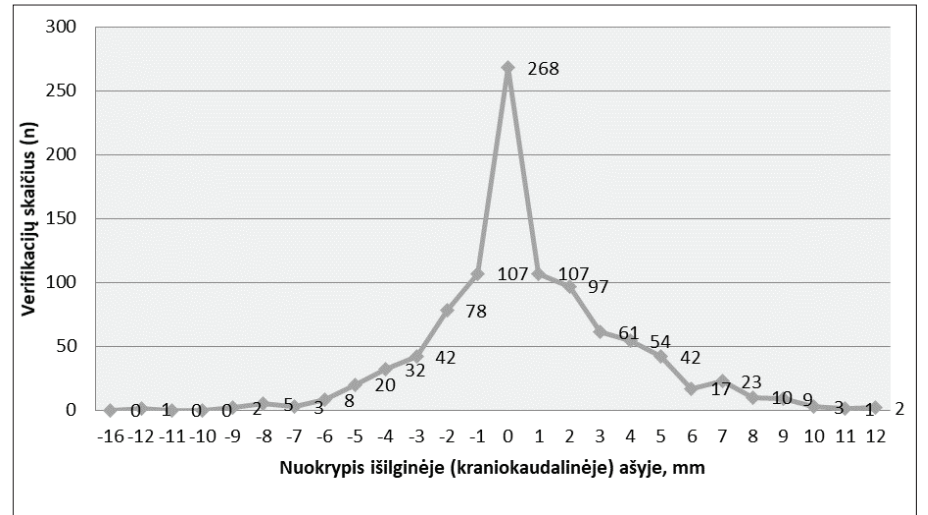

6 pav. Dubens anatominės srities pozicionavimo nuokrypis išilginejje ašyje

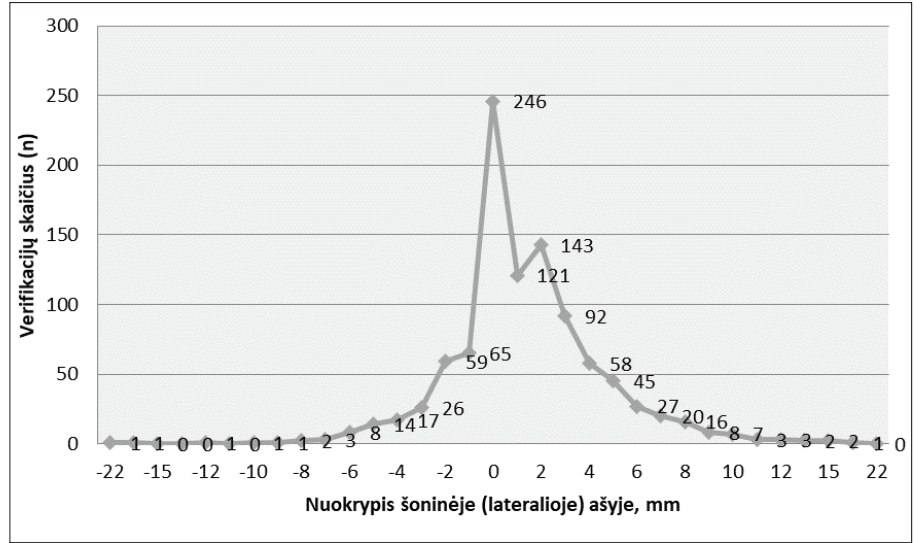

7 pav. Dubens anatominės srities pozicionavimo nuokrypis šoninėje ašyje tynių savaičių radioterapijos laikotarpị mažèjimo tendencija [9-11]. Tai dažniausiai siejama su gerejjančiu šlapimo pūslès išsituštinimu mažèjant navikui bei liekamojo šlapimo tūriui ir netgi dažnesniu šlapinimusi dèl sukelto radiacinio cistito [11]. Šlapimo pūslès padèties ir tūrio pokyčiai skirtingų mokslinių tyrimų duomenimis labai varijuoja $[5,9,10,12]$. Ne visi radioterapijos centrai atlieka kasdienes vaizdines verifikacijas. Dažnai jos kartojamos pirmąsias tris dienas, o po to atliekamos tik kartą per savaitę [13]. Mūsų manymu, naudojant vaizdais valdomą radioterapiją ir siekiant realizuoti radikalią dozę, kasdienès organo ir paciento padèties radiologinès verifikacijos yra reikalingos.

Šio tyrimo trūkumas yra tas, kad šlapimo pūslès CTV pokyčiu įvertinimui pasirinkta mažai pacientų. Gauti rezultatai atskleide, kad vaizdais valdomos šlapimo pūslès véžio radioterapijos esmè - kruopštus judančio organo padèties nustatymas ir paciento pozicionavimas. Atliekant tyrimą buvo pastebèta, kad tik tinkamas paciento imobilizavimas ir kruopštus šlapimo pūslès ištuštinimo instrukcijų išaiškinimas pacientui mažina galimus netikslumus, švitinant sergančiuosius invaziniu šlapimo pūslès véžiu. Paciento pozicionavimo protokolo vykdymas RS atskleide, kad pozicionavimo tikslumo ịvertinimas atitiko šiuolaikinès radioterapijos reikalavimus bei patvirtino, kad planuojant švitinimo tūrị, galimos paklaidos tinkamai ivertinamos.

\section{Išvados}

1. Atliekant tyrimą buvo nustatyta, kad tinkamas paciento imobilizavimas, kruopštus pozicionavimas, šlapimo pūslès ištuštinimo instrukcijų pacientui išaiškinimas ir jų vykdymo kontroliavimas mažina galimus sergančiujų invaziniu šlapimo pūslès vėžiu švitinimo netikslumus.

2. Nesant galimybės prieš kiekvieną procedūrą ìvertinti organo tūrio pokyčių ribų, tikslus paciento pozicionavimo protokolo vykdymas RS, kasdienès radiologinès verifikacijos ir kontrolinis radioterapijos perplanavimas, adaptuojantis prie anatominių struktūrų, šlapimo pūslès ir naviko tūrio pokyčiu, užtikrina saugų radikalios dozès realizavimą.

\section{Literatūra}

1. Witjes JA, MaxBruins H, Cathomas R, Compérat EM, Cowan NC, Gakis G, Hernández V, Linares Espinós E, Lorch A, Neuzillet Y, George M, et al. Association of urology guidelines on muscle-invasive and metastatic 
bladder cancer: summary of the 2020 guidelines. European Urology 2020.

https://doi.org/10.1016/j.eururo.2020.03.055

2. Logue J, McBain CA. Radiation therapy for muscle-invasive bladder cancer: treatment planning and delivery. Clin Oncol (R Coll Radiol) 2005,17:508-13. https://doi.org/10.1016/j.clon.2005.07.004

3. Zhang S, Yu Y-H, Zhang Y, Qu W, Li J. Radiotherapy in muscleinvasive bladder cancer: the latest research progress and clinical application. Am J Cancer Res 2015; 5(2):854-868.

4. Pos F, Remeijer P. Adaptive management of bladder cancer radiotherapy. Semin Radiat Oncol 2010, 20:116-20. https://doi.org/10.1016/j.semradonc.2009.11.005

5. Fokdal L, Honore H, Hoyer M, et al. Impact of changes in bladder and rectal filling volume on organ motion and dose distribution of the bladder in radiotherapy for urinary bladder cancer. Int $\mathrm{J}$ Radiat Oncol Biol Phys 2004,59:436-44. https://doi.org/10.1016/j.ijrobp.2003.10.039

6. Michalski JM, Gay H, Jackson A, et al. Radiation dose volume effects in radiation-induced rectal injury. Int J Radiat Oncol Biol Phys 2010;76 (3 Suppl):S123-S129. https://doi.org/10.1016/j.ijrobp.2009.03.078

7. Henningsohn L, Wijkström H, Dickman PW, et al. Distressful symptoms after radical radiotherapy for urinary bladder cancer. Radiother Oncol 2002,62:215-25. https://doi.org/10.1016/S0167-8140(01)00455-8

8. Marks LB, Yorke ED, Jackson A, et al. Use of normal tissue complication probability models in the clinic. Int J Radiat Oncol Biol Phys 2010;76(3 Suppl):S10-S19. https://doi.org/10.1016/j.ijrobp.2009.07.1754

9. Muren LP, Smaaland R, Dahl O. Organ motion, set-up variation and treatment margins in radical radiotherapy of urinary bladder cancer. Radiother Oncol 2003;69:291-304. https://doi.org/10.1016/S0167-8140(03)00246-9

10. Yee D, Parliament M, Rathee S, et al. Cone beam CT imaging analysis of interfractional variations in bladder volume and position during radiotherapy for bladder cancer. Int J Radiat Oncol Biol Phys 2010;76(4):1045-53. https://doi.org/10.1016/j.ijrobp.2009.03.022

11. Foroudi F, Pham D, Bressel M, et al. Intrafraction bladder motion in radiation therapy estimated from pretreatment and posttreatment volumetric imaging. Int J Radiat Oncol Biol Phys 2013, 86:77-82. https://doi.org/10.1016/j.ijrobp.2012.11.035

12. Mangar SA, Miller NR, Khoo VS, et al.: Evaluating interfractional changes in volume and position during bladder radiotherapy and the effect of volume limitation as a method of reducing the internal margin of the planning target volume. Clin Oncol (R Coll Radiol) 2008, 20:698-704.

https://doi.org/10.1016/j.clon.2008.07.004

13. Kochan A, Rivest R, Galloway K, Lambert P, Ong A, Koul R, Ahmed S, Bashir B, Quon H. Targeting the tumor: assessing the impact of bladder volume and position on accuracy of radiation delivery for patients with bladder cancer. Cureus 2017;9(9):e1638.

https://doi.org/10.7759/cureus.1638

\section{RADIATION THERAPY FOR INVASIVE BLADDER CANCER: IMPACT OF CHANGES IN BLADDER VOLUME CHANGES AND EVALUATION OF SET UP ERRORS IN RADICAL RADIOTHERAPY}

A. Krauleidis, A. Plieskienè, V. Andrijaitienè

Key words: invasive bladder cancer, radiotherapy, imaging guided radiotherapy, set up errors.

Summary

Background and purpose: This study encompass assessment of variations in bladder volume and positioning variations in radiotherapy for invasive bladder cancer in clinic with limited resources.

Methods and material. All patients were positioned for radiotherapy using a customized devices. Daily radiological verifications and weekly rescanned computed tomography images of patients during their radical radiotherapy for invasive bladder cancer were acquired. Bladders were contoured and the volume were compared to the planning CT. Pelvis set up parameters of 30 patients were defined retrospectively and range errors analysis were performed.

Results. There was moderate variability in the mean bladder volumes during the radiotherapy courses. Repeat scan bladder volumes extended outside the planning scan only in rare cases. There were trends for bladder volume reduction during radiotherapy. But in these cases CTV didn't fell outside of the PTV.

Deviations in bladder positions were seen but were small in magnitude. Analysis of pelvis set up parameters showed up to 7390 percent showed small $(+/-3 \mathrm{~mm})$ deviation. The local maximal deviations for all axes (anterior - posterior, lateral and longitudinal) were defined. In conclusion, this study showed a good results for emptying the bladder when patients follow the recommendations and pelvis set up random errors for defining of local PTV ranges were determined.

Correspondence to: plieskiene@kul.lt

Gauta 2020-12-02 